\title{
"Not looking at us level": Systemic barriers faced by Aboriginal teachers in remote communities in Central Australia
}

\author{
Lisa Hall \\ Division of Higher Education and Research, Batchelor Institute
}

\begin{abstract}
This essay is based on doctoral research that examined the reasons behind the low number of young Aboriginal teachers currently undertaking and completing teacher education in remote communities in Central Australia. By listening to the stories of a group of fully qualified and experienced Aboriginal teachers, this doctoral research explored the complex array of barriers, as well as supports, that Aboriginal people from remote communities encounter as educators. The seven teacher participants in this research have each spent between 20 and 35 years working in their respective schools in their home communities (see map below) and have undertaken and completed the requisite study to become fully qualified teachers. The purpose of this essay is to focus exclusively on the examples of systemic barriers experienced by these teachers through the theoretical lens of race, using settler colonial theory, whiteness theory and critical race theory (CRT).
\end{abstract}

Keywords: Aboriginal, teacher, whiteness, race, racism, barriers, settler colonialism, Australia, language, education

\section{Introduction}

Since the 1788 English settlement/colonisation/invasion of the land now known as Australia, along with its subsequent dispossession of Aboriginal people and denial of Aboriginal sovereignty, Aboriginal people in Australia have been positioned by race. ${ }^{1}$

\footnotetext{
${ }^{1}$ The terms Indigenous and Aboriginal are both used in this essay. Wherever possible, the AIATSIS Ethical Publishing Guidelines (2015) have been followed. Where specific known people or groups of people are being referenced the word Aboriginal is used, as none of the participants in this study identify as Torres Strait Islander. Where a more global sense of Indigeneity is being referenced, the term Indigenous is used. It is understood by the author that there are those who find this term unsuitable and even offensive. No offense was intended and my apologies are offered where it has occurred.
} 
Historically, this was done in overt and obvious ways such as the official policy of assimilation (Hasluck et al., 1961). In contemporary Australia, however, this racial positioning happens through much more subtle, insidious and ubiquitous forms. This essay looks at the ways processes of racialization impact Aboriginal teachers working in remote communities. It considers the narratives of seven Aboriginal teachers from Warlpiri (Yuendumu and Nyirripi), Western Arrarnta (Hermannsburg/Ntaria), Luritja (Papunya), and Pitjantjatjara (Areyonga/Utju) communities in Central Australia. ${ }^{2}$

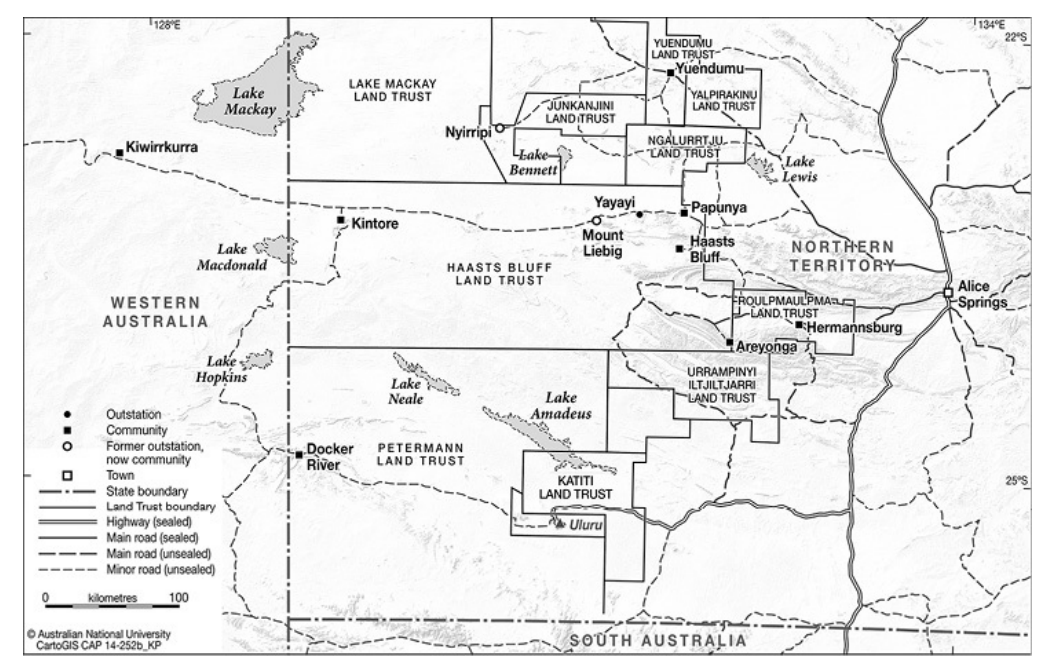

Figure 1. Central Australian home communities of the seven teacher participants (Photo credit: Karina Pelling, CartoGIS, ANU College of Asia and the Pacific)

\footnotetext{
${ }^{2}$ In 2011, I enrolled to do my PhD. This decision came after a long period of working with a group of Aboriginal teachers from remote communities in Central Australia. This group of teachers included seven women from the respective communities of Papunya, Nyirripi, Ntaria/Hermannsburg, Yuendumu, and Areyonga. In our original work together, I was a lecturer supporting the teachers to complete the 4th year of a qualification in teaching. During that period of working together it became clear that all of us shared a very real and passionate concern for the underrepresentation of teachers hailing from the aforementioned communities. After a great deal of discussion, we decided that it would be a good focus for a PhD project. All of the teachers agreed to share their stories with me about how they became teachers, and collectively we decided what important knowledge and ideas we could learn from these stories. This process is further explained in Hall (2016). Publishing this paper is part of the process of sharing what we learned from doing the research together. We are also in the process of publishing the stories of the teachers as a book.
} 


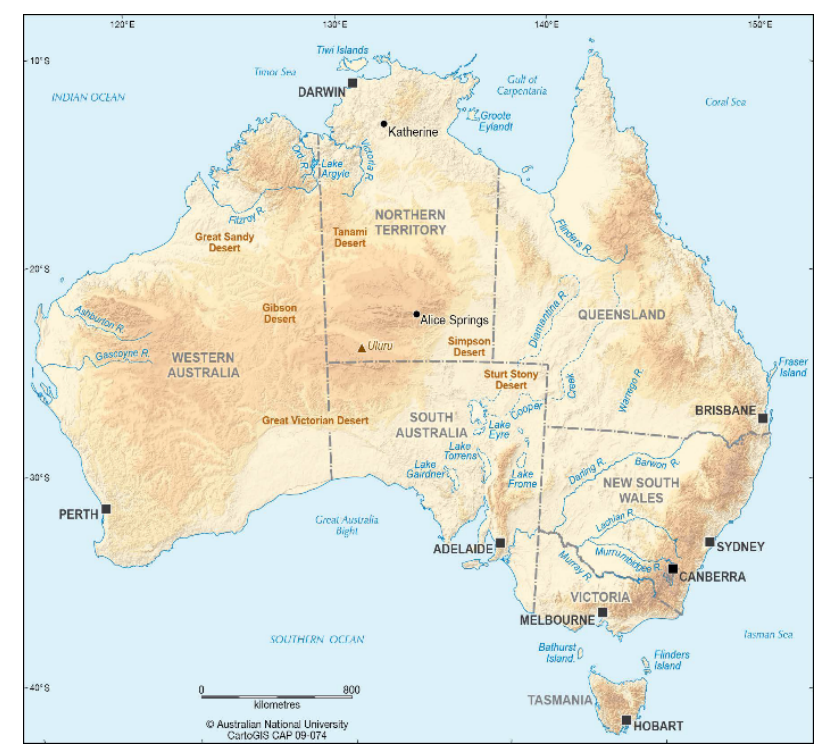

Figure 2. Map of Australia showing the location of Alice Springs (Photo credit: Australian National University, CartoGIS, CAP 09-074)

All of the interviewees have completed the requisite teacher education for full teacher qualification. They have accomplished this, often in spite of the many obstacles woven into the educational systems with which they interact. One example of this is the changing requirements for "full" qualification. In Australia the teaching qualification started as a two-year diploma then changed to a three-year advanced diploma. Qualification now requires a four-year degree. While this is required of all teachers, Aboriginal teachers from remote communities are faced with geographical and language based barriers that make it even more difficult to upgrade their qualifications. Together, their stories offer rich and full accounts of their experiences working for up to 35 years respectively within schools in their home communities. The teacher participants were motivated to participate in this research in order to explore the "common concern" (Verran, 2013) of why so few young people from remote communities in Central Australia are becoming fully qualified as teachers. It was hoped that by listening to these stories this research could collectively offer Australian educators and policymakers a better understanding for how to support Aboriginal people from remote communities in their pursuits to become teachers. However, one of the clearest findings revealed in the participants' narratives was significant barriers that have been encountered during each of their careers. While a number of theoretical approaches could have been applied to the findings, the teachers themselves raised specific and explicit examples of race based barriers in their narratives. It was for this reason that I chose to analyse them through the lens of race. I used settler colonial theory, whiteness theory and critical race theory (CRT) to unpack the narratives of the teachers and explore the ideologies that are embedded deep within systemic and interpersonal practices in education. This essay looks first at the literature related to 
Indigenous Teacher education in Australia, followed by an overview of the methodology used in the study. A background is then provided regarding the theoretical choices and the three theoretical lenses used. The findings themselves are then analysed and broken into three parts: 1) White Possession in Education; 2) Knowledge Status and Whiteness in the Curriculum; and 3) Systemic Whiteness and Institutional Racism. Illustrative examples from the teacher narratives are integrated throughout these three sections before some final conclusions are made.

\section{Literature Review}

Australian and international educational research with Indigenous communities demonstrates the positive outcomes stemming from Indigenous or language minority students being taught by members of their own community who understand their language, culture and learning styles (Christie, 1985; Hickling-Hudson \& Ahlquist, 2003; Santoro \& Reid, 2006; Santoro et al., 2008; Woods, 1994). Race theorists, such as Lipsitz (2006), also argue that,

in order for students to grow, their teachers need to understand and use the students' early experiences in the process of educating them. Teachers must know their students and their environment - the physical and social experiences that have acted as the foundation for what the students know - as such influences provide students with continuity in their own world. (Lipsitz, 2006, p. 4)

There is a strong argument to be made in support of local Aboriginal people becoming qualified teachers in their home communities. Following Lipsitz, they are the ones who implicitly and intrinsically know their students, understand their early experiences, know their environment, understand their social experiences, speak their language, and can provide the continuity required for students to be successful. These epistemological and pedagogical arguments, however, have not always been what has informed the systemic attitudes towards Indigenous teacher education in Australia, and in particular in the Northern Territory of Australia. Apart from a period between the mid to late 1970s and the early 1990s, an era which featured more progressive and culturally responsive educational policies and reforms (Reaburn, 1989; Rogers, 1991; Urvet et al., 1980), systemic attitudes towards Aboriginal teachers in remote communities in the Northern Territory have remained firmly entrenched in the settler colonial and assimilationist mindsets.

There has been considerable investigation into regional and rural Indigenous teacher education in Australia (Reid et al., 2004; Santoro \& Reid, 2006; Santoro et al., 2008). However, in recent years there has been much less investigation around "remote community-based Aboriginal and Torres Strait Islander teacher education" (Patton et al., 
2012, p. 14), and less still of the remote Northern Territory context. Moreover, with the exception of Hall (2012) and Papatraianou, Strangeways, and Beltman (2016), there is next to no research examining Aboriginal teaching in the context of Central Australia.

Additionally, much of the research undertaken on teacher education and teacher pathways has excluded the voices of Aboriginal teachers. Thankfully, within the field of qualitative research, narrative methodologies are growing in prominence. More specifically "yarning", as explained by Bessarab \& Ng'andu (2010), Ober (2017) and Williams (2007), is growing in prominence as an Indigenous methodology. Yarning is now being used to provide a culturally familiar and responsive way of conducting story based research with Indigenous participants. However, it has yet to be used to listen to the voices and stories of Aboriginal teachers in Central Australia. A recent review examining Initial Teacher Education for Aboriginal and Torres Strait Islander Students revealed that the number of Indigenous teachers has failed to increase at a rate envisioned in the 1980s, when the newly formed National Aboriginal Education Committee called for the employment of 1,000 Indigenous teachers by 1990 (Patton et al., 2012, p 9). Since the time the original target was set, numerous other systemic targets have been set without being met, with little interrogation into the reasons why (Gray and Beresford, 2008; Herbert, 2002; Santoro \& Reid, 2006; Vass, 2015). Vass (2015) points towards "something bigger (and) more deep seated" (p. 374) that has long hindered education policy and names that something as "race", or, more specifically, racism. Santoro and Reid (2006) concur, suggesting that "the Australian school system remains a bastion of white cultural supremacy with regard to native and immigrant cultures and peoples" (p. 289). It is both useful and appropriate, therefore, to listen to the stories of Aboriginal teachers from remote communities in Central Australia, which include details about the barriers they experience and analyse these stories through the lenses of settler colonialism and critical race-based theories. These will be explored further below.

\section{Methodology}

The participants for this research were recruited using purposive sampling techniques (Oliver, 2006) based on the following criteria:

- Indigenous (self-identified),

- Fully qualified classroom teacher with a four-year Bachelor degree qualification in Education/Teaching, and

- From a geographically remote community located in Central Australia.

In total, the narratives of seven participants were recorded. This falls within the commonly recommended number for studies of this scope and methodology (Hefferon \& Gil- 
Rodriguez, 2011). Additionally, all of the participants were women, a factor that was not by design but rather a product of the candidates who met the criteria outlined above. In fact, the number and nature of participants was largely determined by the shortage of fully qualified Aboriginal teachers located in remote communities in Central Australia. Importantly, a narrative methodology was chosen because of its compatibility with Indigenous knowledge systems (Hughes et al., 2004; Kovach, 2009; Martin, 2008; Wilson, 2009). The teacher narratives were gathered using unstructured/semi-structured interviewing techniques (Hefferon and Gil-Rodriguez, 2011; Sarantakos, 1998). The recording of the narratives was preceded by a long conversational phase giving each participant the time to fully consider their participation in the research and to be in control of when and where the "telling" would commence. Storytelling focused on the entirety of one's career as a teacher, and was recorded over multiple one-on-one sessions between myself and each participant. These sessions produced a detailed, in depth, and rich account of each teacher's experience. The language of telling was left up to the teacher participant and translation was used where required (often undertaken by the multilingual teacher participants themselves).

The teacher participants were also involved in the analysis work. As part of our commitment to collectivist, generative outcomes in this research it was crucial to ensure that important themes in the narratives were not identified solely by myself, a nonIndigenous person acting as a "detatched, judging observer" but were rather considered by everyone as "participants in a collective activity" (Addelson, 1994, p. 143). In turn, the teacher participants and I analyzed the full set of narratives, giving the teacher participants an opportunity to read and engage with each other's stories. This helped to overcome issues of language and cross-cultural (mis)understanding as teacher participants were given the opportunity to clarify their meaning and unpack any metaphors and symbolism (Pringle et al., 2011). It was based on this group analysis that seven themes were proposed (see Hall, 2016). Many of these related to the barriers faced by the teachers which I then explored through a number of theoretical lenses.

\section{Theoretical Framework}

Many theoretical lenses could be used to examine the stories included herein, including feminist theory and Indigenous Standpoint theory. However, through the process of collective analysis there became a number of instances where teacher participants described the barriers they experienced as racism or race based. Ultimately the interplay between Australia's settler colonial history and the explicit examples of systemic racism experienced by these teachers within the educational system determined the theoretical 
lenses for the study. As such, settler colonialism, whiteness theory, and CRT were the most relevant theories for understanding the specific issues raised in the narratives.

\section{Settler Colonialism}

Initially, this study used Homi Bhabha's theory of Colonial Mimicry (1984) to understand some of the barriers experienced by the teacher participants. However, I received some important feedback reminding me that Australia is a settler colonial nation, whereas Bhabha's work pertains to a franchise colonial state (i.e., India). Veracini (2011) makes an important distinction between settler colonialism and franchise colonialism. In franchise colonialism (e.g., India) the ideology of the colonizer is "I come and you work for me"; in contrast, Veracini argues that the settler colonizer's ideology is "I come and you go away." Wolfe (2006) agrees, suggesting that settler colonialism is inherently eliminatory. He elaborates, writing:

Territoriality is settler colonialism's specific irreducible element ... it strives for the dissolution of native societies ... it erects a new colonial society on the expropriated land base ... settler colonizers come to stay: invasion is a structure not an event ... settler colonialism destroys to replace. (Wolfe, 2006, p. 388)

Wolfe notes that in the specific case of Australia, "Aborigines were accorded no rights to their territory" and that the "theme of terra nullius" became an assumption that was "taken for granted in settler culture" (Wolfe, 2006, p. 391). Australian Indigenous scholar Aileen Moreton-Robinson (2015) stresses the importance of possession within the settler colonizer ideology as well. She notes that "Indigenous people have never been recognized as property-owning subjects in our own right as Indigenous peoples" (Moreton-Robinson, 2015, p. 94). White possession of the land - contemporaneously referred to as Australia, or "unknown Southern Land" - was wholly dependent upon the absolute dispossession of the first peoples. As Iyengar (2014) points out, "the primary aim of the settler nation was not to "sit on top" of native societies, but to eliminate them ... settler society envisioned Native communities as disappearing" (p. 35; emphasis in original). Stark examples of this attitude of elimination litter Australian history from the frontier massacres, to official removal policies that took "half caste" and "quarter caste" Australian Aboriginal children from their families until the 1970s (Wilson \& Human Rights and Equal Opportunity Commission, 1997).

Over time, the political and social ideology of mainstream Australia evolved to understand that "assimilation can be a more effective mode of elimination than conventional forms of killing" (Wolfe, 2006, p. 402). Wolfe (2006) notes that it is this ability to adapt, without losing sight of the ideological imperative of elimination, that makes settler colonialism so "impervious to regime change" and so persistent "over 
extended periods of time" (pp. 402-403). Iyengar (2014) agrees, stating that "a policy shift was needed in regards to Indigenous populations - from elimination-via-expulsion to elimination-via-absorption. But one thing remained the same: the logic of elimination" ( $p$. 51). Settler colonialism thus became "a structuring principle of society across time" (Wolfe, 2006, p. 399). Schools are one of the main institutions through which this structural ideology was and continues to be perpetuated.

\section{Whiteness Theory}

According to McGregor (2006), "whiteness was a treasured quality of early twentieth-century settler Australians, an emblem of their status as a civilised race ... a badge of Britishness ... [a] 'crimson thread of kinship' to affirm the ethnic solidarity of white Australians, both with each other and with their British parent" (p. 511). Writing from an Indigenous Australian standpoint, Moreton-Robinson (2004) suggests that whiteness has taken on an "epistemological a priori" status" that "provides for a way of knowing and being that is predicated on superiority" (p. 74). She argues that this "racial superiority becomes a part of one's ontology, albeit unconsciously, and informs the white subject's knowledge productions" (Moreton-Robinson, 2004, p. 78). The Australian experience, spoken about by Moreton-Robinson, shares some characteristics with other contexts that have a colonial history and face contemporary race based inequalities. Lipsitz (2006), speaking from the North American experience, reminds us that whiteness is not something that only existed back then, in the early days of colonial settlement: "Possessive investment in whiteness today is not simply the residue of conquest and colonialism ... contemporary whiteness and its rewards have been created and recreated by policies" ( $p$. 4). The systems, policies, structures and procedures that organize contemporary society are all based upon socio-historical inequalities and racist ideologies, thus producing the deeply embedded behaviours that reinforce them. Authors such as Lipsitz and MoretonRobinson suggest that whiteness has become a hidden, unmarked, unnamed category against which difference is constructed (Lipsitz, 2006; Moreton Robinson, 2004; Rudolph, 2013). Racist behaviours, attitudes, and language that were once transparent, open, and explicit have, over time, been absorbed into a normalized reality that has enabled racism to continue in covert and ubiquitous ways.

The covert nature of whiteness requires it to be explored at both the systemic and the interpersonal levels. Lipsitz (2006) explains the reason for this, noting that society has become

able to discern as racist only individual manifestations of personal prejudice and hostility. Systemic, collective and coordinated group behaviour consequently drops out of sight. Collective exercises of power that relentlessly channel rewards, 
resources, and opportunities from one group to another will not appear "racist" from this perspective, because they rarely announce their intention to discriminate against individuals. (Lipsitz, 2006, p. 20)

In other words, Lipsitz is suggesting that by limiting the definition of racism to individual and overt acts, the racism that exists at the collective and systemic levels is able to continue unabated. Taylor (2009) expands on this idea further, defining whiteness as a way of talking about a political and legal framework grounded in the ideologies of Western supremacy and the impact of colonialist processes. Vass (2015) also reminds us that it is important to "distinguish between whiteness as a racial discourse and 'white people' as a socially constructed identity and group that are often the beneficiaries of whiteness based on skin colour" (p. 377).

\section{Critical Race Theory}

CRT is a good fit to theoretically analyse the teacher narratives in this research, particularly the themes that relate to racism, exclusion, and invisibility experienced by the teachers. CRT has its origins in critical legal studies (Monaghan, 1993) and can be traced back as far as the early work of Derek Bell (1972). However, in the last two decades, considerable work has been done to use CRT in the context of education (Dixson \& Rousseau, 2006a). CRT considers race as the Central construct for understanding inequality (Ladson Billings \& Tate, 2006). According to Matsuda, Lawrence, Delgado, and Crenshaw (1993), CRT "challenges ahistorism and insists on contextual/historical analysis ... [it] adopts a stance that presumes racism has contributed to all contemporary group advantage and disadvantage" (p. 6). One of the basic premises of CRT is to view claims or notions of "neutrality, objectivity, colour-blindness, and meritocracy" by the dominant knowledge system as "camouflages for the self-interest of powerful entities of society" (Tate, 1997, p. 235). Gillborn (2006) suggests that such notions, despite their veneer of concern for equity and justice, in fact operate as a mechanism by which particular groups are excluded from the mainstream. This makes CRT an important theoretical lens through which to examine the exclusionary experiences outlined in the teacher narratives of this research. In addition to examining overt displays of racism, such as the deliberate exclusion of certain people or groups, CRT helps scholars make sense of the mundane, covert, and everyday expressions of racism that become ingrained parts of contemporary political systems and cultural practices (Delgado \& Stefancic, 2000). The teachers at the centre of this research experienced both overt and covert forms of racism that can be better understood through a CRT analysis.

CRT fits nicely with the other theoretical perspectives used in this research and compliments my methodological choices. While not specifically focused on the settler 
colonial experience, CRT helps scholars interrogate issues of race, systemic racism, and whiteness in their research. CRT and whiteness theory are connected and interrelated. Whereas whiteness theory illuminates how whiteness is organized and understood, CRT provides a deeply critical and radical questioning about the unequal outcomes that race perpetuates. CRT is also a good fit methodologically for this research. A Central tenet of CRT is that it "insists on recognition of experiential knowledge of people of colour and their communities" (Matsuda et al., 1993, p. 6) and does this through the use of storytelling, counter storytelling and narratives (Delgado, 1989; Dixson \& Rousseau, 2006a, 2006b; Gillborn,2006; Ladson Billings \& Tate 2006). It was this unique combination of attributes that made CRT a natural choice for analysing the findings of the research undertaken in this study.

\section{Findings and Discussion}

The findings from the teacher narratives are discussed in three separate sections. The first section explores how settler colonialism continues to shape and impact the experience of Aboriginal people working within Western educational systems. In particular, it looks at the ways that entrenched structural barriers and beliefs prevent Aboriginal teachers from being treated as equals to their non-Indigenous counterparts. The second section explores the inequality of knowledge systems that are deeply embedded parts of educational attitudes, policy, and curricula. Lastly, the third section looks more broadly at examples of "systemic whiteness" that are found in teachers" interactions with the Department of Education, school administrators, and interpersonal interactions with non-Indigenous staff members.

\section{“Not Looking at Us Level”: White Possession in Education}

One of the themes arising from this research highlighted the ways Aboriginal teachers are treated as less than equal to their non-Indigenous colleagues. As one teacher participant commented: "They're not looking at us level." In this instance, "they" refers to the non-Indigenous teachers, principals, and departmental staff who represent the Western educational system. The interviewees often experienced being treated by these individuals as less-than equal to their non-Indigenous counterparts while in the classroom, despite being equally qualified:

...we are qualified teachers. They don't use us as a qualified teacher. They use us to look after the behaviour. (Claire, personal communication, January 15, 2015) 
...I'm just there as a policeman in the classroom. (Maria, personal communication, December 13, 2014)

They're not looking at us level, where we are. We're supposed to be same professional level and they still put us down like we're an AT [Assistant Teacher]. (Brenda, personal communication, May 16, 2014)

We were having a staff meeting. Only non-Indigenous staff they talk to each other instead of talking to Anangu [Aboriginal in Pitjantjatjara language] staff, and one day I banged the table and said to them "Hey we are Anangu staff here, we're not invisible. We want to share our ideas too!” They all stopped talking and put their heads down. I said "You only come and go, but we are here, we stay here for a long time." (Claire, personal communication, January 15, 2015)

...sometimes that team teacher can be like a boss in that classroom, and she's putting me down. (Brenda, personal communication, May 16, 2014)

"You think I'm a student with them?" I told them you know they should recognize us too! (Tania, personal communication, January 15, 2015)

In each of the schools where the interviewees work, the usual practice is to assemble into "teams" in the classroom with a fully qualified teacher working with one or more paraprofessional staff drawn from the local Aboriginal community. These paraprofessional staff are often referred to as Assistant Teachers. Traditionally, Assistant Teachers undertake study while they are working at the school, as was the case with all of the teacher participants in this study. However, access to study opportunities from remote schools is often at the discretion of the local school Principal and dependent upon the support of the qualified, often non-Indigenous, classroom teacher. This creates hierarchical issues in many classrooms, where non-Indigenous teachers impose passive hierachical barriers through their actions such as denying Indigenous staff access to professional development and study opportunities on the grounds that they are needed in the classroom. For example, one teacher participant reported, "In our school we've got tutors as well, and still that's not enough when the AT goes for study and the tutor is there...and I think thats not enough for the white teacher. They're not letting people go" (Maria, personal communication, December 13, 2014). Similar barriers are experienced by the fully qualified Aboriginal teachers who, at times, are placed in "teams" with other fully qualified non-Indigenous teachers, and then treated as less equal. One teacher participant recounted the following experience, "See this lady came into our classroom and she only 
talked to my team teacher and you know I was there also as a teacher, but invisible sitting there" (Brenda, personal communication, November 1, 2014).

Other inequalities are more overt, such as working conditions for Aboriginal versus non-Indigenous teachers. The current Northern Territory Education Department policy holds that non-local recruits must be provided with a fully furnished Education Department house for the duration of their time working in the community. Meanwhile, local recruits are left to find their own accommodation. One teacher participant noted "I'm a teacher and I need to have the same equal rights with kardiya [non-Indigenous] teacher. [They were] just giving us housing, but later on they took that away" (Brenda, personal communication, November 1, 2014) Conversely, one of the other ways that Aboriginal teachers are not "looked at level" is through the expectation that they assume additional roles besides those that are required from their non-Indigenous counterparts. One teacher participant gave the following example:

I've been taking the preschoolers for a year and I haven't had anyone placed with me as an Assitant Teacher becasue they think "Oh she's Indigenous she can do everything!"... They never come and ask or look for someone to work with me. But if a white teacher had five kids oh she'll be screaming her head off. (Maria, personal communication, December 13, 2014)

Remote schools are also highly political and often receive visits on short notice from politicians and other high-ranking government officials for the purpose of policy and program announcements, community consultations, and photo opportunities. In their narratives, the teachers talked about the ways they felt that Principals put them-and other Aboriginal teachers - "on display" when official visitors arrived in the community. They were often pulled out of class with little or no warning, as one interviewee recalled: "Sometimes it's negotiated too by the Principal and whoever is coming, they pull you out, no warning, just come and drag you out" (Lila, personal communication, February 1, 2014). As some of the longest serving educators in their communities who speak the local language, interviewees also mentioned being frequently called upon to act as a liaison between the school, parents, and wider community. This is a role that is exclusively required of local Aboriginal staff:

I think I've got that bigger role ... a lot of the times it's me, called on, and I've got to be seen as the main person, the local person in the school. Yeah sometimes I don't like it! I tell them "No, get that other person!” But ... they really want me ... I guess I've worked there longer [than other Aboriginal staff members]. (Maria, personal communication, December 13, 2014)

All of the teacher participants felt their role expand over the course of their careers, usually without any acknowledgment, additional remuneration, or time-release to take on the extra tasks expected of them. 
It was telling, however, that despite many years of experience, knowledge and practice honing their teaching skills, developing professional qualifications, and working extra hours, these teachers still found it difficult to find institutional support for issues that were epistemologically or pedagogically important to them:

...we used to go to leadership meetings and I used to see them ... couple of Principals ... not where I wanted to see them ... you know I was for that particular program (language and culture) and they were against us. And I thought ... she (the local Principal) was gonna be with me 'cos I was going for programs, but she was against me. (Lila, personal communication, May 31, 2014)

The experience of these teachers is one where many of their non-Indigenous peers and managers understand their role in the education system either as "classroom police" - that is, enforcers trained to keep the students under control for non-Indigenous teachers - or, as translators and cultural liaison contacts with the community. Rarely are these teachers perceived by the non-Indigenous staff as knowledge holders or pedagogues, even though they are qualified as such. They were still frequently treated as less-than-equal by the "come and go" (Hall, 2012) non-Indigenous Principals, teachers and departmental staff.

Many of the barriers experienced by these Aboriginal teachers, as revealed through their narratives, can be understood through the lens of settler colonial theory. Wolfe (2006) reminds us that settler colonialism must be seen as an ongoing "structure" rather than an "event" that occurred once in the past. In the context of Australia, the white possession of education is the structural foundation upon which remote schools in Central Australia have been built, and within which these Aboriginal teachers are working. When these teachers talk about feeling invisible or treated unequally, they provide insight into the lived experience of settler colonialism, which continues to strive for "elimination" (Iyengar, 2014) of the "native society" (Wolfe, 2006). Moreton-Robinson (2015) suggests that much of the ideology of settler colonialism as it relates to white possession is strengthened and perpetuated, not through overt and highly visible mechanisms, but through interpersonal discourse and relationships. She argues that:

The pervasiveness of the nation's white possessiveness functions through social institutions such as the workplace, operating in everyday intersubjective relations between Indigenous and white subjects. These daily intersubjective relations are the mechanisms by which the exercising of white possession is experienced by Indigenous people as racism. (Moreton-Robinson, 2015, p. 94)

In fact, the workplace is one of the primary sites for ensuring the continuation of the settler colonial project in Australia. Moreton-Robinson (2015) points out that Aboriginal people experience workplaces as environments that support and normalize the behavior and attitudes of their "white workmates." She notes that many Aboriginal people experience differential treatment from their white counterparts though actions such as having their 
qualifications queried or being denied access to professional development and advancement opportunities (Moreton-Robinson, 2015). Moreton-Robinson names "white race privilege and advantage" as "unearned invisible assets that benefit white people in their everyday lives" and amount to "possessions" (Moreton-Robinson, 2015, p. 97). She notes that assets or possessions such as these, and the spaces they play out in - such as public institutions - are "derived from and contribute to the normalization of white possessiveness, which remains invisible to white people in everyday practice" (MoretonRobinson, 2015, p. 97).

The white possession of a public space, such as a school, is called into question by the mere presence of Aboriginal teachers - particularly when they are qualified to do the same job as their white counterparts. This presence creates a "threat" to white possession, which often becomes a "catalyst for the collective closing of ranks" (Moreton-Robinson, 2015, p. 98) amongst white staff who want to protect that possession. Behaviour such as this is particularly evident in remote Aboriginal communities where white possession is made even more tenuous by the absence of other white infrastructure and people. In contrast, the local Aboriginal teachers have strong historical, linguistic, cultural, and familial ties to the land that exceed the walls of the school. Wolfe (2006) draws on the work of Deborah Bird Rose (1991) to highlight this disruption of white possession in settler colonial mindsets: "So far as Indigenous people are concerned, where they are is who they are ... to get in the way of settler colonization, all the native has to do is stay at home" (Wolfe, 2006, p. 388; emphasis in original). As such, Aboriginal teachers who are motivated to become qualified and teach in their home communities pose a unique threat to the white possession of schools located therein. Barriers and behaviours in these workplaces are established to ensure that the participation of qualified local Aboriginal teachers in remote schools remains conditional upon the fact that the white possession of the school space remains in place.

\section{Knowledge Status and Whiteness Enshrined in Curricula}

The teacher participants in this research experienced powerful forms of exclusion through the educational system's prioritization of the English language and Western forms of knowledge. One participant pointed to decision-making practices around the curriculum, explaining that Principals insist that some elements of the curriculum are taught while others are ignored:

How come this curriculum, this is what you've got to do in the classroom and this

Principal, boss, does the wrong things ... We've got that language and culture

program in the school and they've got nothing to lose, white teachers, if that program goes, 'cos they've got these other programs, English ones ... They can just 
change, change, change the program. We've only got this one program that we want to hold onto and it's very sad to see it go ... It's important, we want to hold onto it. It comes with our identity. They don't care. (Maria, personal communication, December 13, 2014)

This behavior and attitude was specifically noted by one participant in relation to the history of bilingual education in remote communities in the Northern Territory:

They would change that bilingual program into a "literacy program" which was not the full idea of bilingual, only few things that they would pick out to make it look like bilingual but you call it "literacy program" to run in the school. (Brenda, personal communication, May 16, 2014)

The relegation of local Indigenous knowledge to "Language and Culture" programs, combined with the subsequent centrality of the "literacy and numeracy" agenda - which prioritizes English literacy and Western numerical understandings - in Indigenous education also powerfully exemplifies curriculum priorities that research participants identified and struggled with. Indigenous knowledge is frequently seen by non-local educators in remote schools as a discrete unit to be taught in isolation, often referred to as "language and culture," or as a perspective to be tacked onto core units of work. It is rarely seen as the foundation upon which the school curriculum could be based, using the local community language and knowledge base of Elders. Iyengar (2014) reminds us that "language policies and language ideologies have been central to the ... settler-colonial project” (p. 57). Programs involving Aboriginal languages are constantly under threat of having their funding reduced or cut altogether and are at the constant mercy of reactive policy responses, as evidenced by the overnight parliamentary decision to introduce a "Four hours of English" policy in 2008 (Northern Territory Government, 2008). The status of Aboriginal language programs was thus reduced to shallow cultural engagements with foods, songs, dancing, and folktales (Ladson-Billings \& Tate, 2006) without acknowledging the deep knowledge base from which these practices emerge. Such an approach fails to engage with the fundamentally different, but equally important, conceptions of knowledge held by Indigenous peoples, and highlights the ways in which settler colonialism continues to permeate Australian education through its erasure of Aboriginal cultural practices and assimilationist curriculum (Veracini, 2011).

An ever-narrowing curriculum focus and heavy emphasis on standardized testing also creates a number of entrenched inequalities. In Australia, these changes are best represented by the implementation of the National Assessment Program Literacy and Numeracy (NAPLAN) tests, being conducted with students in years three, five, seven, and nine of their studies. Remote schools in the Northern Territory are consistently reported as performing well below national levels in NAPLAN test results. And, despite almost 10 years of NAPLAN testing, there has been very little overall change in the literacy and 
numeracy of Australian students. In fact, Rice (2016) reports that "on average, students based at schools in major cities perform the best. This is followed by those in inner regional locations, then outer regional locations. In remote and very remote areas, average achievement is lowest." Political philosopher and social justice theorist Iris Marion Young (1990) points out that "standardised testing, while often presented as value-free and neutral, has been found to give advantage to those of the dominant culture as the tests often reflect particular value choices and cultural meanings" (p. 209). It is hardly surprising, in other words, that urban-centric, middle class, English speaking students are reported to perform best on NAPLAN testing, as the tests are developed by those who share urban, middle class, English speaking values and cultural meanings. Standardized mechanisms of this kind are key to the perpetuation of structural inequality within educational systems.

The recent emphasis on "literacy and numeracy" has also infiltrated the teacher education system in light of the 2014 "Action Now: Classroom Ready Teachers" report, recommending that "entrants to initial teacher education programs ... have personal literacy and numeracy levels broadly equivalent to the top 30 per cent of the population" (Action Now: Classroom Ready Teachers, 2014, p. 12). By making this a benchmark requirement, the cultural and linguistic background, knowledge, language and skills of teacher education candidates have also become standardized underneath the veil of whiteness.

The introduction of literacy and numeracy benchmarks for teachers indicates an important power differential in terms of who decides what is important in a curricula sense and how those priorities become defined and enacted. As Moreton-Robinson (2004) explains, whiteness views itself as an epistemological a priori. In other words, it assumes a dominance and superiority for its own way of knowing and being above all other ways of knowing and being. In remote schools, attended largely by Aboriginal language speaking students, most non-Indigenous teachers will come into an educational space and assume that their way of knowing is primary and superior to other ways of knowing and should therefore take priority in the children's learning. Such a framework for the production of particular types of knowledge is steeped in the political history that arrived in Australia with the colonisers (Moreton-Robinson, 2000), and remains particularly evident in schools where the majority student population comes from a different cultural background compared to the majority of teachers. Qualified Aboriginal teachers who share the language and knowledge background of students, therefore, are faced with a constant battle to justify space in the curriculum for locally based ways of knowing. The teacher participants in this research specifically indicated that this form of knowledge exclusion might well be a reason that would discourage other Aboriginal people from pursuing further education and training. 


\section{Systemic Whiteness and Institutional Racism}

In the early decades after the colonisation of Australia it was common for overt displays of racism and prejudice to exist in the language and attitudes of colonisers with regards to Aboriginal people. Words such as "savage, low order, primitive, barely human, barbaric, dying race, blacks and mentally inferior" were variously used to describe Aboriginal people to justify the exclusion of Aboriginal people from education (Russo, Cavanaugh, Rodwell \& Northern Territory University, 1989, p 2). Overt and explicit displays of racism such as these continue in the contemporary moment, but are less widespread in Australia. Gillborn (2006) explains this social change suggesting that we now find ourselves in an era of "the development of increasingly racist and exclusionary education policies that operate beneath the veneer of professed tolerance and diversity ... de-politicized and managerialist language of school effectiveness and improvement" ( $p$. 11). Through these mechanisms, whiteness has been ubiquitously embedded into educational institutions at the departmental level, the leadership level and the interpersonal level. That is to say, the settler colonial and assimilationist ideology is still alive and well in schools, and in particular in remote Northern Territory schools.

The teacher participants in this research were all acutely aware of the power and control over the daily operation of their local community schools held by the "government" (the Federal or Northern Territory levels of Government), "the Department" (the Education Department of the Northern Territory) or "the Office" (the regional headquarters of the Education Department of the Northern Territory). This was often experienced in the resourcing and funding of programs and staffing in their schools, as one teacher participant explained: "...we used to have a secondary class too but government now I don't know, government cutting funding and teachers" (Claire, personal communication, January 15, 2015). At other times it was experienced as an absence of support due to the fact that teachers were employed to teach in their home community but treated differently from equally qualified, non-Indigenous neophyte teachers. They did not receive the orientation to work that most new teachers received:

So when I first became a teacher in my classroom they said "yeah go ahead this is all your stuff and...teach!” But there were also rules there, and laws from education, I was expected to learn them but I didn't have anyone telling me, I had to go alone and just trying to do my best. (Fay, personal communication, January 12, 2015)

Others spoke of exclusion in the absence of opportunities for advancement:

I see you know teachers who are there a long time I see them get into new roles, stepping out of the classroom and given a professional jobs like ESL, coordinator or mentor for teaching teachers who are first out-jobs like that you know...I wanted to be with them so that education in Indigenous communities can you know go how 
we want it to go and I really wanted to step in to do that, but there was no support. (Lila, personal communication, May 17, 2014)

In addition to experiencing barriers to career advancement, these teachers spoke of many instances when "The Department" intervened at the school level. This was particularly evident for the teachers once they became fully qualified and started having a small amount of power and control over school-based decisions:

...must be someone in the Office is changing, awa...changing and putting white fellas and pushing Anangu outside. (Claire, personal communication, January 15, 2015)

We did a lot of study, a lot of hard work...something came across and took it over...maybe for couple of years I took over, then something came over and pushed me out (of a position of power an authority in the school)...Maybe Education Department you know. I'm thinking you know, I'm thinking other way round, maybe Education Department you know, they're not looking at us because we are Aboriginal. That's why. Because of our skin. (Tania, personal communication, January 15, 2015)

In considering her more than 30 years of work in education, and the fact that she had once held considerable authority in the school, Tania reflected for some time on the feeling of being "pushed out." In our conversation, she spoke of it being like a Mamu (monster) that had come through like a menacing presence. When I pushed her to explain what she meant, she spoke of the power of non-Indigenous people to exert influence in Aboriginal circles, despite existing outside those circles. She felt that Aboriginal teachers were not looked at in the same way as non-Indigenous teachers and she chose to name such behaviour as overt institutional racism.

In many instances the school Principal became the local instrument of "The Department." Many of the teacher participants commented on the high turnover of Principals, the power they yield, and the damage accruing from their short tenures at the school:

...we had a lot of changes of our Principals, yeah they come with different ideas. Some would come with "I'm not gonna be a friend here, I'm just here to clean up the mess" you know "with my power." (Brenda, personal communication, November 1, 2014)

...some (non-Indigenous) teachers left because of her, yeah they said "I can't work when she's here, I will come back when there's another Principal." (Naomi, personal communication, February 23, 2014) 
One of the ways that research participants described Principals wielding their power was to create a veneer of consultation with Aboriginal teachers, only to act independently and/or according to the wishes of "The Department":

I don't know why she comes and asks me?... if she's not going to listen, just to make me happy, show me the piece of paper, so I can't think "Oh I'm part of this as well” ... She didn't really want to listen to me. (Maria, personal communication, December 13, 2014)

He had that power for himself to rule over us and he wasn't listening. (Brenda, personal communication, November 1, 2014)

...things were happening around, like Principal would speak to a staff member or other Tjulkurra [non-Indigenous person] instead of telling or asking me ...Principal would take it over and start doing it on his own. (Lila, personal communication, February 1, 2014)

Research participants also spoke of the Principals using their power to reinforce their own position and security within the system. One participant (Teacher participant B) remarked "They come with bad powers." Others said:

She [the non-indigenous Principal] wants to do it her own way...she was using her own power to run her [an Aboriginal teacher] down, run over her...she did that with her own power but she didn't share that with others (Lila, personal communication, May 17, 2014)

...he (the Principal) already had a high position when he's a Principal, but giving that ET2 (leadership) position to his family which no teachers there didn't get it. Even us as a Yapa [non-Indigenous in the Warlpiri language] teacher, lawa [no/nothing in the Warlpiri language]. (Brenda, personal communication, May 16, 2014)

In the narrative conversations, one teacher participant explicitly questioned the promotion of non-local persons without knowledge of Indigenous cultures to high-level positions in her school. For that participant, knowledge of Indigenous cultures seemed an appropriate and necessary pre-requisite to work in a remote school. She made the comparison that to attain an equally high position she would have to demonstrate a high level of knowledge and competence in the Western educational system:

...and someone that's not really, you know...never has learned anything about Indigenous culture is always going to be throwing things at you, you know, blocking it. He pretends he knows but the way what he talks about it doesn't make any sense to me....he doesn't know what to say about it, to respond ... If an 
Indigenous person want(s) to be in a higher position (we've) got to go through all, got to face all that, but sometimes you know non-Indigenous teacher ignores and try and push it back. (Maria, personal communication, December 13, 2014)

When understood through the lens of settler colonial theory, the struggles between Aboriginal teachers and administrators are hardly surprising. Centralized control and homogeneity have always been part of the settler colonial project. Wolfe (2006) reminds us that settler colonialism "presupposed a global chain of command linking remote colonial frontiers to the metropolis" (p. 394). In the context of remote Aboriginal schools in Central Australia, this dynamic plays out in the form of the centralized departmental office located in the "metropolis" (i.e., the urban centres where the majority of Australians live), which exercises power and control over the "colonial frontier" of the remote school. Those non-Indigenous teachers and leaders who are envoys of the "office" carry the weight and power of the "metropolis" and exercise control over the local Aboriginal people on its behalf.

This kind of control can also be exacted through policy. A key example is the creation of "Professional Standards for Teachers" (Australian Institute for Teaching and School Leadership, 2011), and its discourses surrounding "quality teaching." Both the umbrella term "quality teachers" and the set of Professional Standards for Teachers, against which all Australian teachers are assessed at four stages ranging from "graduate," "proficient," "highly accomplished," and "lead" (AITSL 2017), serve as tools for defining what is meant by quality. Both also originate from a white, English speaking, urban, and Westernized epistemological perspective. Despite this, they are presented as representatives of "transcendent, acontextual, universal ... truths or procedures" (LadsonBillings \& Tate 2006, p. 20). Weilbacher (2012) puts it succinctly asserting that "standardization is Whiteness" and labelling educational standards a "current powerful example of the deliberate nature of dominance" (p. 2). The "quality" discourse is portrayed as "educational common sense" (Gillborn 2006, p. 12), but such an assumption, I argue, is dangerous in that it sets up an invisible binary and suggests an objective truth when defining what is meant by "quality." That is, if something can be measured as high quality then other things can be relegated as low or lower quality. These are examples of what Leonardo (2009) calls "whiteness as policy" that rely on "race-neutral" assumptions that wilfully ignore the political and socio-historical events that originally created and now sustain inequality. In these ways, settler colonial power relationships remain embedded in Australian education discourses and institutions, despite administrators' overt and stated concern for equity and inclusion (Rudolph, 2013). The rhetorical intentions of "The Department" and school leadership might include a discussion of more qualified Aboriginal teachers and the up-skilling of Aboriginal staff, but this is conditional upon it 
happening within a white, unflinchingly Western, epistemological system that remains intent on elimination.

Another (arguably more insidious) manifestation of exclusionary power to emerge from the interviews appeared, at first glance, to be workplace friendship or kindness. Upon more examination, however, research participants identified the motivations and intentions behind such kindness as something they needed to be wary of. Research participants described how Principals, in particular, would point to personal issues that a qualified Aboriginal teacher may be experiencing as an opportunity to relegate that individual to paraprofessional and assistant level positions in ways that would likely be unimaginable if the teachers were white. For example:

[Principal said] "You will still be a teacher" ... but not on the salary side, palya? It's only Assistant Teacher pay...he was trying to help me like "you're having problems at home and getting stressed, and I want to help you." (Claire, personal communication, January 15, 2015)

This kind of backhanded "help" is identified by Dixson \& Rousseau (2006b) as "false empathy" (p. 41). Dixson and Rousseau identify false empathy as a paternalistic form of empathy, which is a common characteristic of "white liberals" (p. 41). Delgado (1996) also refers to this idea of false empathy as a moment when a "white believes he or she is identifying with a person of colour, but in fact is doing so only in a slight, superficial way" (p. 12) or indeed helping someone less fortunate than them navigate a situation in what a white person would perceive as a "fundamentally just society" (p. 91). Friere's (1972) notion of "false generosity" (p. 21) also alludes to similar behaviours, and points out that any change in status - particularly the advancement of those being helped - threatens the position of the helper. False empathy and false generosity are two more mechanisms of whiteness that exist to perpetuate power divides and reinforce the status quo. Lipsitz (2006) reminds us that the racially privileged are possessively invested in the status quo and will behave in ways that protect that privilege.

At the interpersonal level racism often manifests in a "dysconscious" way (Delgado, 1989; King, 1991; Wellman, 1977). Wellman (1977) posits that dysconscious racism is a form of racism that tacitly accepts dominant white norms and privileges. It is not the absence of consciousness but an impaired, distorted, or uncritical consciousness about race. Uncritical ways of thinking about racial inequity mean that individuals accept certain culturally sanctioned assumptions, myths, and beliefs that justify the social and economic advantages white people have amassed through ongoing forms of colonial violence. Many non-Indigenous teachers go to work in remote schools with "good intentions" but, as Applebaum (2010) points out, the "good intentions" of teachers can go awry because these same teachers have benefited from the education system, leaving them to sometimes operate from a default position of protecting and reproducing the status quo. 
The Aboriginal teacher participants in this study were clearly able to identify many layers and forms of systemic and institutional racism that impacted their work in schools. All seven teacher participants spoke of being treated differently because of race, whether it be through the decisions made at the departmental level, or the attitudes, behaviours and choices of the school Principal. The teacher participants also talked about the ways that this played out at an interpersonal level through their interactions with non-Indigenous colleagues who appeared to be supportive, but whose actions were geared towards reinforcing their own position in the educational hierarchy. The work of early CRT scholar Derek Bell is referred to by Delgado and Stefancic (2000) who point out that often "white elites will tolerate or encourage racial advances for blacks only when such advances also promote white self-interest" (p. xvii). Vass (2015) agrees with this point, highlighting that one of the mechanisms of protecting the long-term interests of whiteness is by enabling only incremental gains for Aboriginal people in education. Thus, even though they may not be fully conscious of the impact of their behaviours, non-Indigenous educators dysconsciously act in ways that protect whiteness and assert the dominance of a Western epistemological standpoint. This, of course, emanates from the original ideology of settler colonialism, which has at its foundation the desire to completely eliminate Indigeneity. All of these systemic constructs and exclusionary behaviours are cumulative acts of elimination.

\section{Conclusion}

The teacher participants in this research have experienced many racist barriers during their years of involvement with the Western education system. These can be better understood when seen through the theoretical lenses of settler colonialism, whiteness, and critical race theory, as this essay has done. White systems and structures of control, as exemplified in this research from remote Northern Territory schools of Australia, have stayed true to the original goal of eliminating an Indigenous presence wherever possible. These systems and structures of control have done this over the course of history, if not through death, then through subtle, invisible, weapons of exclusion and Trojan horses of assimilation. Terms such as "quality," nationalised standards, and compulsory "literacy and numeracy" are examples of such weapons. So too is a "culturally neutral" national curriculum. To teach in this context, in other words, requires one to ensure the ongoing hegemony of "universal" educational norms - or, put another way, to continue to facilitate the status quo that privileges white-focused frameworks of knowing. Occasionally, in remote schools in the Northern Territory, localised and contextualized programs have emerged that have sought to give voice and space to Indigenous epistemologies and 
languages, such as the bilingual program in the Northern Territory. However, these types of programs are received as "threats" to the ongoing settler colonial project, are often themselves under threat of funding cuts, and I have argued, serve as a reminder of the failure to completely eliminate Indigeneity. In response, white possession and power is restored through funding decisions, policy changes and other systemic changes to the education system.

Some rare Aboriginal individuals have managed to persevere, complete all the requirements, and become fully qualified teachers. The narratives upon which this research was based revealed that the Aboriginal teachers who are resilient, determined, and dedicated enough to pursue this path have often had to compromise, negotiate, betray, and alter both themselves and their knowledges along the way, leaving them with a number of difficult epistemological and ontological choices. However, their stories also depict a work environment that still refuses to accept their professional equality, despite having spent years overcoming obstacles and making personal and spiritual sacrifices. At the interpersonal level, these teachers have faced attitudes and behaviours from school Principals and non-local staff for whom the cultural superiority complex is so deeply embedded that they are not even conscious of it. Using the interpersonal tools of white possession, those privileged by whiteness often close ranks to exclude and treat Aboriginal teachers as invisible in order to protect white hegemony and possession. Such hostile work environments and systemic barriers make educational domains unsafe and unwelcoming for Aboriginal people wanting to become teachers.

\section{References}

Action Now: Classroom Ready Teachers. (2014). Teacher education ministerial advisory group. Final Report. Department of Education, Canberra, Australia. Retrieved from http://www.studentsfirst.gov.au.

AIATSIS. (2012). Guidelines for ethical research in Australian Indigenous studies.

Australian Institute of Aboriginal and Torres Strait Islander Studies. Retrieved from http://aiatsis.gov.au.

AITSL. (2017). Australian professional standards for teachers. Australian Institute for Teaching and School Leadership. Retrieved from http://www.aitsl.edu.au.

Applebaum, B. (2010). Being white, being good: White complicity, white moral responsibility, and social justice pedagogy. Lanham, MD: Lexington Books.

Addelson, K. P. (1994) Moral passages: Toward a collectivist moral theory, New York: Routledge. 
Bell, D. (1972). Race, racism and American law. Boston, MA: Little, Brown and Company.

Bessarab, D., \& Ng'andu, B. (2010). Yarning about yarning as a legitimate method in Indigenous research. International Journal of Critical Indigenous Studies, 3(1), 3750.

Bhabha, H. (1984). Of mimicry and man: The ambivalence of colonial discourse. The MIT Press, 28, 125-133.

Christie, M. (1985). Aboriginal perspectives on experience and learning: The role of language in Aboriginal schools. Geelong, Australia: Deakin University Press.

Delgado, R. (1989). Storytelling for Oppositionists and Others: A Plea for Narrative. Michigan Law Review, 87(8), 2411-2441.

Delgado, R. (1996). The coming race war: And other apocalyptic tales of America after affirmative action and welfare. New York, NY: NYU Press.

Delgado, R., \& Stefancic, J. (2000). Critical race theory: The cutting edge. Philadelphia, PA: Temple University Press.

Dixson, A. D., \& Rousseau, C. K. (2006a). Critical race theory in education: All God's children got a song. New York, NY: Taylor \& Francis.

Dixson, A. D., \& Rousseau, C. K. (2006b). And we are still not saved: Critical race theory in education ten years later. In A.D. Dixson and C.K. Rousseau (Eds.), Critical race theory in education: All God's children got a song (pp. 31-54). New York, NY: Taylor \& Francis.

Freire, P. (1972). Pedagogy of the oppressed. Harmondsworth, UK: Penguin.

Gillborn, D. (2006). Critical race theory and education: Racism and anti-racism in educational theory and praxis. Discourse: Studies in the Cultural Politics of Education, 27(1), 11-32.

Gray, J., \& Beresford, Q. (2008). A “formidable challenge": Australia's quest for equity in Indigenous education. Australian Journal of Education, 52(2), 197-223.

Hall, L. (2016). Moving deeper into difference - Developing meaningful and effective pathways into teacher education for Indigenous adults from remote communities. (Doctoral Dissertation). Charles Darwin University, Northern Territory, Australia. Retrieved from http://espace.cdu.edu.au.

Hall, L. (2012). The 'come and go' syndrome of teachers in remote Indigenous schools: Listening to the perspective of Indigenous teachers about what helps teachers to stay and what makes them go. The Australian Journal of Indigenous Education, 41(2), 1-9.

Hasluck, P., Robertson, H. S, Hills, P., Porter, M. V., Noble, H. W., Pearson, G. G., Perkins, C. C., Smith, G. C. (1961, January). The Policy of Assimilation. In P. Hasluck (Chairman) Decisions of the commonwealth and State Ministers at the 
Native Welfare Conference. Native Welfare Conference Canberra, Australia. Retrieved from http://aiatsis.gov.au.

Hefferon, K., \& Gil-Rodriguez, E. (2011). Interpretative phenomenological analysis. The Psychologist, 24(10), 756-759.

Herbert, J. (2002). Introduction. In J. Herbert (Ed.) Learning journeys: Indigenous teachers sharing their success stories. Townsville, Australia: James Cook University.

Hickling-Hudson, A., \& Ahlquist, R. (2003). Contesting the curriculum in the schooling of Indigenous children in Australia and the United States: From eurocentrism to culturally powerful pedagogies. Comparative Education Review, 47(1), 64-89.

Hughes, P., More, A. J., \& Williams, M. (2004). Aboriginal ways of learning. South Australia: Flinders Press.

Iyengar, M. (2014). Not mere abstractions: Language policies and language ideologies in U.S settler colonialism. Decolonization: Indigeneity, Education \& Society, 3(2), 3359.

King, J. E. (1991). Dysconscious racism: Ideology, identity, and the miseducation of teachers. Journal of Negro Education, 60(2), 133-146.

Kovach, M. (2009). Indigenous methodologies: Characteristics, conversations, and contexts. Toronto, ON: University of Toronto Press.

Ladson-Billings, G., \& Tate IV, W. (2006). Toward a critical race theory of education. In A. D. Dixson \& C.K. Rousseau (Eds.) Critical race theory in education: All God's children got a song (pp. 11-30). New York, NY: Taylor \& Francis.

Leonardo, Z. (2009). Race, whiteness, and education. New York, NY: Routledge.

Lipsitz, G. (2006). The possessive investment in whiteness: How white people profit from identity politics. Philadelphia, PA: Temple University Press.

Martin, K. L. (2008). Please knock before you enter: Aboriginal regulation of outsiders and the implications for researchers. Teneriffe, Australia: Post Pressed.

Matsuda, M. Lawrence, C. R. Delgado, R., \& Crenshaw, K. W. (1993). Words that wound: Critical Race Theory, Assaultive Speech, and the First Amendment. Boulder, CO: Westview Press.

McGregor, R. (2006). The necessity of Britishness: Ethno-cultural roots of Australian nationalism. Nations and Nationalism, 12(3), 493-511.

Monaghan, P. (1993, June 23). Critical race theory questions the role of legal doctrine in racial inequity. Chronicle of Higher Education, A7-A9.

Moreton-Robinson, A. (2015) White possessive. Minneapolis, MN: University of Minnesota Press. 
Moreton-Robinson, A. (2004). Whiteness, epistemology and Indigenous representation. In A. Moreton-Robinson (Ed.) Whitening race: Essays in social and cultural criticism (pp. 75-88). Canberra, Australia: Aboriginal Studies Press.

Northern Territory Government Newsroom. (2008, October 13). Education restructure includes greater emphasis on English. (Media release). Retrieved from http://newsroom.nt.gov.au.

Ober, R. (2017). Kapati Time: Storytelling as a Data Collection Method in Indigenous Research. Learning Communities: International Journal of Learning in Social Contexts, 22, 8-15.

Oliver, P. (2006). Purposive Sampling. In V. Jupp (Ed.) The SAGE dictionary of social research methods (pp. 244-245). London, UK: SAGE.

Papatraianou, L., Strangeways, A., \& Beltman, S. (2016, December). Becoming a teacher in Central Australia: Picturing resilience through arts-based research methods. Paper presented at Australian Association for Research in Education Conference, Melbourne, Australia.

Patton, W., Hong, A. L., Lampert, J., Burnett, B., \& Anderson, J. (2012). Report into the retention and graduation of Aboriginal and Torres Strait Islander students enrolled in Initial Teacher Education. MATSITI - ACDE Retention and Completion Report, Queensland University of Technology and Australian Council of Deans of Education. Retrieved from: http://eprints.qut.edu.au.

Pringle, J., Drummond, J., McLafferty, E., \& Hendry, C. (2011). Interpretative phenomenological analysis: A discussion and critique. Nurse Researcher, 18(3), 2024.

Reaburn, S. (1989). From "proper" to appropriate: A case study of the development towards successful formal teacher education for Aboriginal educators. (Unpublished master's thesis). Northern Territory University, Darwin, Australia.

Rice, S. (2016, December 12). NAPLAN results reveal little change in literacy and numeracy performance - here are some key takeaway findings. ABC news online. Retrieved from http://www.abc.net.au/news/2016-12-13/naplan-key-takeawaysfrom-results/8114880

Rogers, K. (1991). Blakbala Kaltja at Ngukurr Community School. In National Aboriginal and Torres Strait Islander Pedagogy Project \& Deakin-Batchelor Teacher Education Program. Aboriginal pedagogy $=$ Blekbala wei $=$ Deme nayin $=$ Yolngu rom $=$ Ngini nginingawula = Ngaewurranungurumagi: Aboriginal teachers speak out (pp. 144-150). Geelong, VIC: Deaking University Press.

Rose, D. B. (1991). Hidden histories: Black stories from Victoria River Downs, Humbert River and Wave Hill Stations. Canberra, Australia: Aboriginal Studies Press. 
Rudolph, S. (2013). Whiteness in education: How are notions of educational success in Australia influenced by images of whiteness? In C. Behar, \& A. Chung (Eds.) Images of whiteness (pp. 207-220). Oxford, UK: InterDisciplinary Press.

Russo, S. \& Cavanagh, D. M., 1939- \& Rodwell, G 1944- \& Northern Territory University. Faculty of Education (1989). An interpretive history of Aboriginal education in Australia and the NT. Faculty of Education, Northern Territory University, [Casuarina, N.T.].

Santoro, N., \& Reid, J.A. (2006). "All things to all people": Indigenous teachers in the Australian teaching profession. European Journal of Teacher Education, 29(3), 287-303.

Santoro, N., Reid, J., Simpson, L., \& McConaghy, C. (2008, November). Exploring the career experiences of Indigenous teachers: Beyond policy and resource initiatives. Paper presented at Australian Association Researchers Education Conference, Brisbane, Australia.

Sarantakos, S. (1998). Social research (2nd ed). Victoria, Australia: MacMillan Education. Tate, W. F. (1997). Critical race theory and education: History, theory, and implications. In M. W. Apple (Ed.). Review of research in education (pp. 195-247). Washington, DC: American Educational Research Association.

Taylor, E. (2009). The foundations of critical race theory in education: An introduction. In E. Taylor, D. Gillborn, \& G. Ladson-Billings (Eds.). The foundations of critical race theory in education (pp. 1-13). New York, NY: Routledge.

Urvet, M., Heatley, A., \& Alcorta, F. (1980). A study in transition: Education and policy making in the Northern Territory-The education policy process at state level, and Australia United States Comparative Study. Monograph no. 8. Parkville, Australia: Centre for the Study of Higher Education, University of Melbourne.

Vass, G. (2015). Putting critical race theory to work in Australian education research: "We are with the garden hose here." The Australian Educational Researcher, 42(3), 371-394.

Veracini, L. (2011). Introducing settler colonial studies. Settler Colonial Studies, 1, 1-12.

Verran, H. (2013). Engagements between disparate knowledge traditions: Toward doing difference generatively and in good faith. In L. Green (Ed.) Contested ecologies: Dialogues in the South on nature and knowledge (pp.141-161). South Africa: HSRC Press.

Weilbacher, G. (2012). Standardization and whiteness: One and the same? Democracy \& Education, 20(2),1-6.

Wellman, D. (1977). Portraits of white racism. Cambridge, MA: Cambridge University Press. 
Williams, S. (2007). Indigenous values informing curriculum and pedagogical praxis. (Unpublished doctoral dissertation). Deakin University, Geelong, Australia.

Wilson, R. D., \& Australia Human Rights and Equal Opportunity Commission. (1997). Bringing them home: Report of the National Inquiry into the Separation of Aboriginal and Torres Strait Islander Children from their Families. Sydney, Australia: Human Rights and Equal Opportunity Commission.

Wilson, S. (2009). Research is ceremony: Indigenous research methods. Black Point, NS: Fernwood Publications.

Wolfe, P. (2006). Settler colonialism and the elimination of the native. Journal of Genocide Research, 8(4), 387-409.

Woods, D. (1994). Discussion paper on Aboriginal and Torres Strait Islander Education. Curriculum Perspectives, 14(4), 26-35.

Young, I. M. (1990). Justice and the politics of difference. Princeton, NJ: Princeton University Press. 